Sains Malaysiana 49(4)(2020): 859-870

http://dx.doi.org/10.17576/jsm-2020-4904-15

\title{
A New Crescent Moon Visibility Criteria using Circular Regression Model: A Case Study of Teluk Kemang, Malaysia
}

(Kriteria Baru Kebolehnampakan Bulan Sabit menggunakan Model Regresi Berkeliling: Suatu Kajian Kes Teluk Kemang, Malaysia)

\author{
NaZhatulShima Ahmad*, Mohd Saiful Anwar Mohd NAWAWI, Mohd Zambri ZainudDin, Zuhaili Mohd \\ NASIR, ROSSITA MOHAMAD YUNUS \& IBRAHIM MOHAMED
}

\begin{abstract}
Many astronomers have studied lunar crescent visibility throughout history. Its importance is unquestionable, especially in determining the local Islamic calendar and the dates of important Islamic events. Different criteria have been used to predict the possible visibility of the crescent moon during the sighting process. However, so far, the visibility models used are based on linear statistical theory, whereas the useful variables in this study are in the circular unit. Hence, in this paper, we propose new visibility tests using the circular regression model, which will split the data into three visibility categories; visible to the unaided eye, may need optical aid and not visible. We formulate the procedure to separate the categories using the residuals of the fitted circular regression model. We apply the model on 254 observations collected at Baitul Hilal Teluk Kemang Malaysia, starting from March 2000 to date. We show that the visibility test developed based on elongation of the moon (dependent variable) and altitude of the moon (independent variable) gives the smallest misclassification rate. From the statistical analysis, we propose the elongation of the moon $7.28^{\circ}$, altitude of the moon of $3.33^{\circ}$ and arc of vision of 3.74 at sunset as the new crescent visibility criteria. The new criteria have a significant impact on improving the chance of observing the crescent moon and in producing a more accurate Islamic calendar in Malaysia.
\end{abstract}

Keywords: Circular regression; crescent moon; lunar month; q-test; visibility criteria

ABSTRAK

Ramai ahli astronomi telah mengkaji kebolehnampakan bulan sabit sepanjang sejarah. Kepentingannya tidak dapat dipertikaikan, terutama dalam menentukan kalendar Islam tempatan dan tarikh peristiwa penting Islam. Kriteria yang berbeza telah digunakan untuk meramalkan kemungkinan kebolehnampakan bulan sabit semasa proses pencerapan. Walau bagaimanapun, setakat ini, model kebolehnampakan yang digunakan adalah berdasarkan teori statistik linear, sedangkan pemboleh ubah penting dalam kajian ini adalah dalam sukatan membulat. Oleh itu, dalam kertas ini, kami mencadangkan ujian kebolehnampakan baru menggunakan model regresi berkeliling, yang akan membahagikan data menjadi tiga kategori kebolehnampakan; dapat dilihat dengan mata kasar, mungkin memerlukan bantuan optik dan tidak kelihatan. Kami memformulasi prosedur tersebut untuk memisahkan kategori menggunakan sisa model regresi berkeliling yang sesuai. Kami mengaplikasikan model tersebut dalam 254 pemerhatian yang dikumpulkan di Baitul Hilal Teluk Kemang Malaysia, bermula dari Mac 2000 sehingga kini. Kami menunjukkan bahawa ujian kebolehnampakan dibangunkan berdasarkan pemanjangan bulan (pemboleh ubah bersandar) dan ketinggian bulan (pemboleh ubah bebas) memberikan kadar salah pengkelasan terkecil. Daripada analisis statistik, kami mencadangkan pemanjangan bulan pada $7.28^{\circ}$, ketinggian bulan $3.33^{\circ}$ dan aras penglihatan $3.74^{\circ}$ ketika matahari terbenam sebagai kriteria baharu kebolehnampakan bulan sabit. Kriteria baharu ini memberi kesan yang besar dalam meningkatkan peluang melihat bulan sabit dan menghasilkan kalendar Islam yang lebih tepat di Malaysia studied.

Kata kunci: Bulan lunar; bulan sabit; kriteria kebolehnampakan; regresi berkeliling; ujian q

\section{INTRODUCTION}

Main religions in the world, including Jews, Hindu, and Islam, have their calendars based on lunar month. They are mainly used to determine dates of important events or festivals in each religion. As a result, the determination of criteria to indicate the expected visibility of the crescent moon is of utmost importance since the time of Babylon Era (Ilyas 1994). The criteria are mainly derived based on the crescent moon data collected at end of the month. The variables measured include elongation (Elon), altitude of the moon $(\operatorname{Alt}(M))$, altitude of the sun $(\operatorname{Alt}(S))$, arc of vision $(A R C V)$, width of the crescent moon $(W)$, lag time between sunset and moonset (lag time), and age of the crescent 
moon from conjunction (age). The choice of the parameters for the criteria mainly correspond to the minimum contrast between the brightness of the moon and the sky. That is, we look at certain values such that the moon is bright enough, or the sky is dark enough for the crescent moon to be seen. For example, the Babylonians used age and lag time as a measure of brightness of the moon and the sky, respectively (Bruin 1977). Here the lag time is at least 48 min after sunset, and this value has changed since.

In the past, different studies report the criteria based on a different set of variables measured in crescent moon sighting activities. Among the early Arabic astronomers, Al-Tabari utilized the depression angle of the sun in the visibility of the crescent moon. The crescent would be considered visible at the time of moonset if the altitude of the sun was $9.5^{\circ}$ below the horizon (Guessoum \& Meziane 2001; Hogendijk 1988). In the more recent centuries, most models were built based on the observations made by Julius Schmidt in Athens, Greece, from 1859-1880 (Schaefer 1988). Based on 76 sets of observations of the crescent moon, Fotheringham (1910) established necessary specific criteria, which include the relative altitude of the moon with respect to the sun's altitude (known as an arc of vision, $A R C V$ ). By placing a line of separation between the negative and positive crescent moons, Fotheringham (1910) gave a minimum limit of an $A R C V$ of $12^{\circ}$ and a relative azimuth of $0^{\circ}$. Maunder (1911) formulated a smaller minimum limit than Fotheringham (1910), which is $11^{\circ} \mathrm{ARCV}$ at $0^{\circ}$ relative azimuths, for when the crescent moons can be seen, as he suggested there was a technical issue with the negative data reported by Fotheringham. Ilyas (1988) examined the $A C R V$ and its relative azimuth criteria and found the criteria proposed by Fotheringham (1910) and Maunder (1911) were limited to a difference in azimuth of $20^{\circ}$. At a larger scale, these criteria cannot be applied. Consequently, to match his criteria of elongation of $10.4^{\circ}$, Ilyas (1988) concluded that the minimum limit of $A R C V$ was supposedly $10.5^{\circ}$ with a relative azimuth of $0^{\circ}$. Recently, Raharto et al. (2019) presented the allpossible moon astronomical position at sun-set time in a diagram of $\operatorname{Alt}(M)$ vs Elon and the azimuth difference of the moon and the sun. Then, by analysing the importance of different variables considered in the study, they came up with a set of new criteria based on the arc of light with values $6^{\circ}$ or $6.4^{\circ}$ depending on the visibility on equatorial and subtropical observation.

In recent years, discussion on the criteria focussed on the Danjon limit (Danjon 1936). In the year 1931, the French astronomer André Danjon measured 75 moon samples observed using a theoretical approach. He estimated the length of the crescent moon by measuring the parts of the moon illuminated by sunlight. Crescent is expected to be visible if the elongation is more than $7^{\circ}$, hereafter known as the Danjon limit (Fatoohi et al. 1998). Further improvement of the criteria was later published. McNally (1983) suggested that atmospheric seeing causes the crescent to be obscured when it is smaller than the seeing disk. He concluded that the Danjon limit is supposed to be $5^{\circ}$ rather than $7^{\circ}$. However, Schaefer (1991) explained that atmospheric seeing is not the main factor in the deficiency of the arc. He developed a model and suggested $7^{\circ}$ as the new Danjon limit for the crescent to be visible. Ilyas (1983) stated that the Danjon limit is intended to be a general guide. However, for the formation of calendar regulation, elongation of $10.5^{\circ}$ is the best. Fatoohi et al. (1998) and Odeh (2004) studied the observational reports and respectively concluded that $7.4^{\circ}$ and $6.4^{\circ}$ as the estimated Danjon limits. Sultan (2007) and Hasanzadeh (2012) developed a photometric model of crescent visibility and re-evaluated the Danjon limit to be $5^{\circ}$.

Different mathematical approaches have been used to arrive at the values the criteria. McNally (1983) studied mathematically the effect of atmosphere on the shape of crescent moon and formulated the width as a measure of shortening the crescent moon in terms of $\theta$ and $\phi$, where $\theta$ $=180-\chi, \chi$ being the elongation of the earth from the sun as viewed from the moon centre and $\phi$ is the position of outer terminator near the cusp. He suggested the atmospheric factor should be considered in order to maximize the length of the outer terminator. The poor seeing condition will cause a shortened terminator of the crescent moon. However, Schaefer (1991) later argued that atmospheric factor is not important by considering the Hapke's lunar surface brightness measure.

Ilyas (1994) reviewed the development of criteria, especially in producing universal international Islamic calendar amid the challenge for quality crescent moon data. A unified approach of five practical considerations is proposed to come up with a universal international Islamic calendar in the future. Yallop (1997) introduced the q-test as a test of the visibility of the crescent by considering the residuals of the fitted polynomial regression model of $A R C V$ on the width of crescent moon. Several different categories of visibility are proposed. Hoffman (2003) provided a collection of crescent moon data set observed in good weather conditions. He used to update the criteria of the q-test and further claimed that the data could be used to validate any visibility tests. Similarly, Odeh (2004) combined data set from different studies and used them to come up with the new values of the existing criteria. Hasanzadeh (2012) used the weighted polynomial function of the arclength of crescent moon against elongation and obtained a new value of the Danjon limit by extrapolating the curves to the case of zero arc length. Recently, Alrefay et al. (2018) analysed the relationship between different pair of variables. In particular, they proposed the hypothetical curve which can best separated the observations with positive/negative crescent moon visibility in terms of $W$ and $A R C V$.

So far, the development of the criteria uses only linear statistical theory. However, most of the variables in crescent moon data are measured in degree/radians. Hence, in this paper, we consider the circular statistical theory to come up with new criteria for the visibility of local 
crescent moon data. The proposed criteria follow closely the methods adopted by Yallop (1997) for the q-test. This paper is organized as follows: In the next section, we present the background of the data collected at the main observing station in Malaysia. Then, the circular statistical theory used in this study is covered in subsequent section while the development of the new tests is in section that follows. In the following section, we presents the findings of the study. Discussion on the results and conclusion are included in the last section.

\section{OBSERVATIONS AND DATA COLLECTION}

We carried out the crescent moon sighting activities at Baitul Hilal Teluk Kemang (Latitude: $2^{\circ} 27$ ' 44" N, Longitude: $101^{\circ} 51$ ' $21^{\prime \prime} \mathrm{E}$, height: $14 \mathrm{~m}$ above sea level). Historically, this site was the first location in Malaysia used for sighting the crescent moon in the 1970s. During the years, the observations were conducted only for three lunar months (29th of Ramadhan, Syawal, and
Zulkaedah of Hijr) each year to determine the start of the fasting month, Eid al-Fitr and Eid al-Adha, until 1999. The observations were conducted using theodolites operated by the surveyors and the committee of crescent moon observation to validate the visibility if it is sighted. Starting in March 2000, the observation has been carried out consistently on the 29th and 30th of each lunar months until now. We used various equipment and methods in the observations, such as theodolites, portable telescopes of 12 -inch reflector and $76 \mathrm{~mm}$ refractor, and the naked eye. The images of the crescent moon were then recorded using a DLSR camera.

We have collected 254 data since $2000(1420 \mathrm{H})$ which consists of 81 positive data, and the rest of the data are not visible due to bad weather and severe sky conditions, and due to the very low values of the criteria to be observed. Table 1 and Figure 1(a) and 1(b) respectively show the definition and diagram of the geometric variables used for the sun and moon.

TABLE 1. The definition of geometric variables used for the sun and moon

\begin{tabular}{ll}
\hline Variable & \multicolumn{1}{c}{ Definition } \\
\hline$W$ & $\begin{array}{l}\text { Width of the crescent moon as view from the earth, measured in } \\
\text { arcminutes }\end{array}$ \\
Alt $(S)$ & Altitude of the sun \\
Alt $(M)$ & Altitude of the moon \\
ARCV & $\begin{array}{l}\text { Arc of vision, i.e. the geocentric difference in the altitude between the } \\
\text { centre of the sun and the centre of the moon for a given latitude and } \\
\text { longitude with taking into account the effects of refraction }\end{array}$ \\
& $\begin{array}{l}\text { Elongation, which refers to the angle between the centre of the sun } \\
\text { and the centre of the moon, as viewed from earth }\end{array}$ \\
Status & $Y=$ visible, $N=$ not visible \\
\hline
\end{tabular}

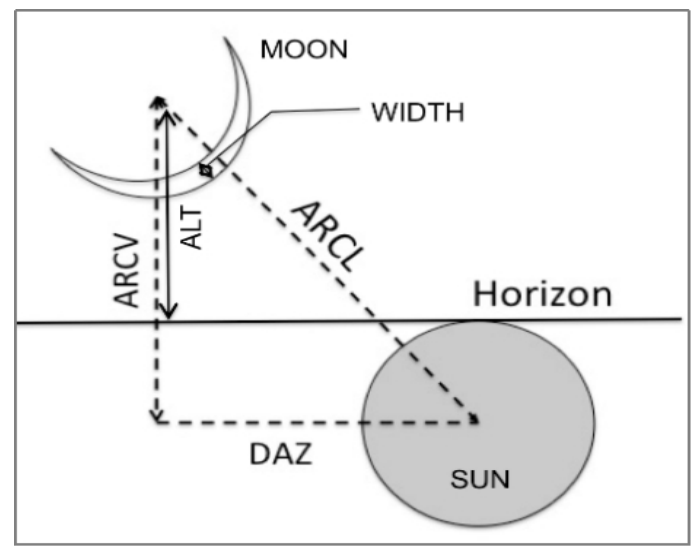

FIGURE 1 (a). Schematic diagram of geometric variables of the Sun and moon at sunset: ARCV, relative altitude between the center of the moon and the sun; ALT, altitude of the center of the crescent moon above the horizon; DAZ, azimuth difference between the sun and moon; ARCL is equivalent to elongation; and Width, the crescents width 


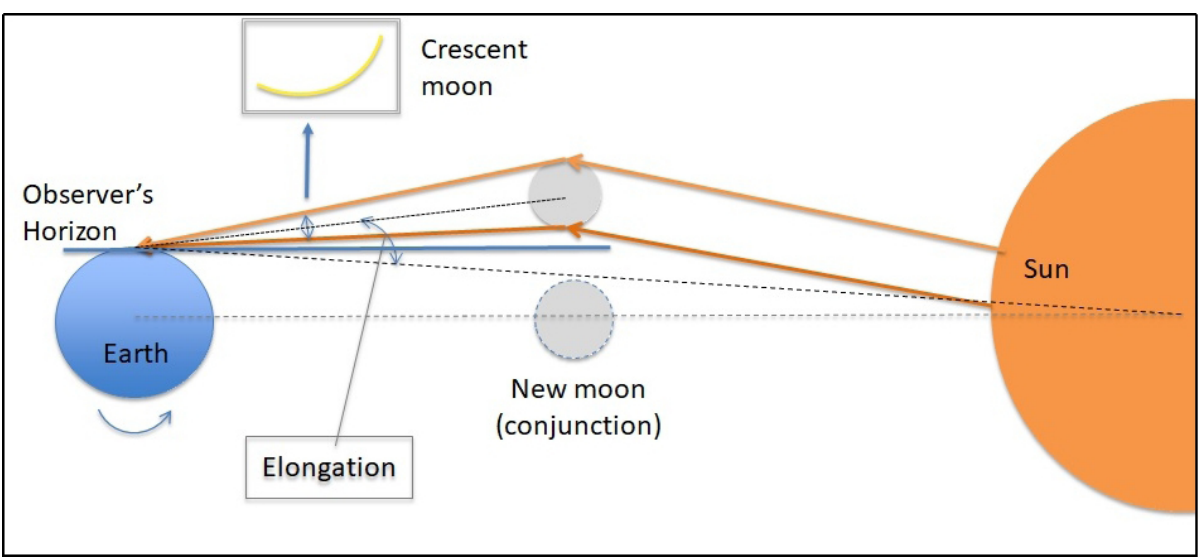

FIGURE 1 (b). Global view of the geometric variables of the sun and moon after a few hours of conjunction; Elongation is an angle between the center of the sun and the moon as seen from the Earth and the reflected of light from the moon after several hours of conjunction called the crescent

\section{METHODS}

We note that the five variables considered in Table 1 are circular; that they are measured in radian or degree. One of the important properties of circular variables is the bounded property of the variables such that the observed values taken are within the range $(0,2 \pi)$. Recent papers in circular regression models and their diagnostic tools include Alkasadi et al. (2018) and Kim and Rifat (2019). Here, we intend to use the relevant theory in circular statistics in order to come with a better visibility test for crescent moon detection. Detail is available in Jammalamadaka and SenGupta (2001).

\section{MEASURES FOR CIRCULAR VARIABLES}

To describe any circular data set, we need some measures of location and dispersion. Let $\theta_{1}, \ldots, \theta_{n}$ be observations in a random circular sample of size $n$ from a circular population.

\section{Mean direction}

To summarize the circular data, we use the mean direction as a measure of tendency. For a given circular random sample, we consider each observation to be a unit vector whose direction is specified by the circular angle and find their resultant vector. The mean direction is defined by the angle made by the resultant vector with a horizontal line. Specifically, we have the resultant length $R$ given by,

$$
R=\sqrt{C^{2}+S^{2}}
$$

where $C=\sum_{i=1}^{n} \cos \theta_{i}$ and $S=\sum_{i=1}^{n} \sin \theta_{i}$. The mean direction, $\bar{\theta}$, may be obtained by solving the equations, $\cos \bar{\theta}=\frac{C}{R}$ and $\sin \bar{\theta}=\frac{S}{R}$, where

$$
\bar{\theta}=\left\{\begin{array}{lcc}
\tan ^{-1}(S / C), & \text { if } & S \geq 0, C>0, \\
\frac{\pi}{2}, & \text { if } & S>0, C=0, \\
\tan ^{-1}(S / C)+\pi, & \text { if } & C<0, \\
\tan ^{-1}(S / C)+2 \pi, & \text { if } & S<0, C \geq 0, \\
\text { undefined, } & \text { if } & S=0, C=0 .
\end{array}\right.
$$

One of the mean direction characteristics is that $\sum_{i=1}^{n} \sin \left(\theta_{i}-\bar{\theta}\right)=0$, which is analogous to the linear case.

\section{Concentration parameter}

The concentration parameter, denoted by $\kappa$, is a standard measure of dispersion for $\mathrm{c}$ distribution. Best and Fisher (1981) gave the maximum likelihood estimates of the concentration parameter $K$ as follows:

$\hat{\kappa}=\left\{\begin{array}{lll}2 \bar{R}+\bar{R}^{3}+5 / 6 \bar{R}^{5}, & \text { if } & \bar{R}<0.53 \\ -0.4+1.39 \bar{R}+0.43 /(1-\bar{R}), & \text { if } & 0.53 \leq \bar{R}<0.85 \\ \left(\bar{R}^{3}-4 \bar{R}^{2}+3 \bar{R}\right)^{-1}, & \text { if } & \bar{R} \geq 0.85\end{array}\right.$

where $\bar{R}$ is mean resultant length and is given by $\bar{R}=\frac{R}{n}$. The larger the value of concentration parameter, the more concentrated the data towards the mean direction.

\section{Median, quantile and percentile}

Mardia and Jupp (1972) defined the median as any point $\phi$, where half of the data lie in the arc $[\phi, \phi+\pi)$ and the other points are nearer to $\phi$ than to $\phi+\pi$. Basically, for any circular sample, Fisher (1993) defined the median direction as the observation which minimizes the summation of circular distances to all observations $\theta_{1}, \ldots, \theta_{n}$, that is, $d(\phi)=\pi-\sum_{i=1}^{n}|\pi-| \theta_{i}-\phi||$. Fisher's 
definition is used to obtain the circular median in the Oriana statistical software package. On the other hand, the first and third quantile directions $Q_{1}$ and $Q_{3}$ are any solution of

$$
\int_{\phi-Q_{1}}^{\phi} f(\theta) d \theta=0.25 \text { and } \int_{\phi}^{\phi+Q_{3}} f(\theta) d \theta=0.25
$$

respectively. $Q_{1}$ can be considered as the median of the first half of the ordered data and $Q_{3}$ as the median of the second. The percentiles can then be obtained by further splitting the ordered sample.

\section{CIRCULAR CORRELATION}

Special measure of correlation has been developed for any two circular variables. Given $\left(\theta_{1}, \beta_{1}\right), \ldots,\left(\theta_{n}, \beta_{n}\right)$ is a random sample of observations measured as angles. As for measuring the correlation between two circular variables, we use the sample circular correlation given by

$$
r_{\theta \beta}=\frac{\sum_{i=1}^{n} \sin \left(\theta_{i}-\bar{\theta}\right) \sin \left(\beta_{i}-\bar{\beta}\right)}{\sqrt{\sum_{i=1}^{n} \sin ^{2}\left(\theta_{i}-\bar{\theta}\right) \sum_{i=1}^{n} \sin ^{2}\left(\beta_{i}-\bar{\beta}\right)}}
$$

where and are sample mean directions. As in the linear case, takes values in the range and the closer to 1 or -1 indicates the stronger relationship between the variables. The relationship for circular variables can also be described using spoke plot (Zubairi et al. 2008).

\section{CIRCULAR REGRESSION MODEL}

Due the bounded property of circular variables, various circular regression models have been proposed to model the relationship between 2 circular variables, see for example in Hussin et al. (2004). Here, due to its simple property and possibility to be extended to a general case, we consider the regression model proposed by Jammalamadaka and Sarma (1993), (JS hereafter) for two circular random variables $\boldsymbol{U}$ and $\boldsymbol{V}$ in terms of the conditional expectation of $e^{(i v)}$ given $u$ given by,

$$
E\left(e^{-i v} \mid u\right)=\rho(u) e^{-i \mu(u)}=g_{1}(u)+i g_{2}(u)
$$

where $e^{i v}=\cos v+i \sin v, \mu(u)$ represents the conditional mean direction of $v$ given $u$ and $p(u)$ the conditional concentration parameter for some periodic function $g_{1}(u)$ and $g_{2}(u)$. Equivalently, we may write

$$
\begin{gathered}
E(\cos v \mid u)=g_{1}(u) \\
E(\sin v \mid u)=g_{2}(u)
\end{gathered}
$$

We may then predict $v$ such that

$$
\mu(u)=\hat{v}=\arctan \frac{g_{2}(u)}{g_{1}(u)}= \begin{cases}\tan ^{-1} \frac{g_{2}(u)}{g_{1}(u)} & \text { if } g_{1}(u)>0 \\ \pi+\tan ^{-1} \frac{g_{2}(u)}{g_{1}(u)} & \text { if } g_{1}(u) \leq 0 \\ \text { undefined } & \text { if } g_{1}(u)=g_{2}(u)=0\end{cases}
$$

The difficulty of non-parametrically estimating $g_{1}(u)$ and $g_{2}(u)$ leads us to approximate them by using suitable functions, taking into account they are both periodic with period $2 \pi$. The approximations used are the trigonometric polynomials of suitable degree $m$ of the form

$$
\begin{aligned}
& g_{1}(u) \approx \sum_{k=0}^{m}\left(A_{k} \cos k u+B_{k} \sin k u\right) \\
& g_{2}(u) \approx \sum_{k=0}^{m}\left(C_{k} \cos k u+D_{k} \sin k u\right)
\end{aligned}
$$

We therefore have the following models:

$$
\begin{aligned}
& \cos v=\sum_{k=0}^{m}\left(A_{k} \cos k u+B_{k} \sin k u\right)+\varepsilon_{1} \\
& \sin v=\sum_{k=0}^{m}\left(C_{k} \cos k u+D_{k} \sin k u\right)+\varepsilon_{1}
\end{aligned}
$$

where $\boldsymbol{\varepsilon}=\left(\varepsilon_{1}, \varepsilon_{2}\right)$ is the vector of random errors following the normal distribution with mean vector $\mathbf{0}$ and unknown dispersion matrix $\Sigma$. The parameters $A_{k}, B_{k}, C_{k}$, and $D_{k}$, where $k=0,1, \ldots, m$, the standard errors as well as the dispersion matrix $\Sigma$ can then be estimated using the generalized least squares estimation method. As for the errors, we use the definition of circular distance as given Jammalamadaka and SenGupta (2001) such that,

$$
e=\pi-|\pi-| v-\hat{v}||
$$

where $\hat{v}$ is the estimated value of $v$.

\section{THE CRESCENT MOON VISIBILITY TESTS}

In this section, we revisit the q-test proposed by Yallop (1997) and propose new tests based on circular regression model.

\section{THE $Q$-TEST}

In developing new crescent moon visibility tests using circular regression model, we follow closely the $q$-test of Yallop (1997). The test is based on the topocentric crescent width, $W$, and geocentric $A R C V$. Yallop's algorithm computed crescent visibility based on the residuals resulting from the fitted polynomial regression $A \widehat{R C} V=11.8371-6.3226 \mathrm{~W}+0.7319 \mathrm{~W}^{2}-0.1018 \mathrm{~W}^{3}$ on 295 observations compiled by Schaefer (1996). The residuals are then divided by 10 giving the $q$-statistic,

$$
q=\frac{[A R C V-A \widehat{R C} V]}{10} .
$$


He further defined five different categories depending on the visibility of crescent moon using various instruments and non-visible categories for $q<-0.293$ as described in Table 2.

TABLE 2 . The $q$-test types by Yallop (1997)

\begin{tabular}{|c|c|c|}
\hline Types & $q$-test value & Justification \\
\hline A & $q>+0.216$ & Easily visible to the unaided eye ( $\geq 12 \mathrm{ARCV}$ ) \\
\hline B & $-0.014<q<+0.216$ & Visible under certain atmospheric conditions \\
\hline $\mathrm{C}$ & $-0.160<q<-0.014$ & $\begin{array}{l}\text { May need optical aid to find the thin crescent } \\
\text { moon before it can be seen with the unaided eye }\end{array}$ \\
\hline $\mathrm{D}$ & $-0.232<q<-0.160$ & Can only be seen with binoculars or a telescope \\
\hline $\mathrm{E}$ & $-0.293<q<-0.232$ & $\begin{array}{l}\text { Below the normal limit for detection with a } \\
\text { telescope }\end{array}$ \\
\hline $\mathrm{F}$ & $q<-0.293$ & Not visible below the Danjon limit \\
\hline
\end{tabular}

Hoffman (2003) investigated the validity of the Yallop (1997) criteria using the results of 539 observations of the moon made over several years by many experienced observers in good weather conditions. The data were selected from 1047 reports. He proposed a three-category of visibility type namely; the crescent moon is visible if $q$ is higher than 0.43 and not visible if $q$ is less than -0.06 . These suggest that different data set may give different ranges of the categories.

We also applied the same $q$-test on our 254 data, and we found that the lowest value of the $q$-test with a positive crescent sighting is -0.347 . This value is significantly lower than the minimum limit of the $q$-test by Yallop (1997). Though the $q$-test value is lower, the elongation of the crescent moon is $11.33^{\circ}$, which is higher than the Danjon limit. The inconsistent values of the test make this $q$-test very subjective, and the value cannot be used as a standard limit for crescent moon visibility.

\section{THE NEW CRESCENT MOON VISIBILITY TEST}

The main interest of this work is to find alternative crescent visibility tests besides the $q$-test. The new test is developed by generalizing the derivation of the $q$-test by Yallop (1997) based on the circular regression model. The new crescent moon visibility test utilizes two circular variables, say $U$ and $V$ only. We fit the variable $U$ on $V$ using the JS circular regression model, as described in Circular Regression Model section, giving $\hat{u}$, the fitted values of $u$. Hence, we define the $U V$-statistic as

$$
U V=\pi-|\pi-| u-\hat{u}|| .
$$

As in the $q$-test, we use the resulting residuals from the JS circular regression model on two circular variables to categorize the visibility of the crescent moon. We then attempt to classify the residuals into different groups and relate the groups according to the visibility of the crescent moon. We achieve that by taking the following steps:

First, find the $99 \%, 95 \%$, and $90 \%$ confidence intervals of the residuals, namely [L99, U99], [L95, U95] and [L90, U90], respectively. Next, form 7 categories,

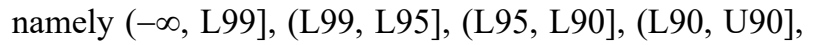
(U90, U95], (U95, U99], (U99, $\infty)$. After that, tabulate the frequency of crescent moon visibility/non-visibility for each category. Lastly, reduce the number of categories based on the tabulated frequencies.

In cases considered, we reduced the categories into three groups associated with 'Visible to the unaided eye', 'May need optical aid', and 'Not visible'. These categories will then be finalized, and the performance of the test is investigated.

\section{RESULTS AND ANALYSIS}

\section{CIRCULAR DESCRIPTIVE ANALYSIS}

The distribution of the values of the circular variables can be described by a rose diagram, as depicted in Figure 2 . The data are mainly concentrated and close to zero. These show the condition of an early phase of the moon after the sunset. Table 3 provides the mean, minimum/ maximum, and the $95 \%$ confidence interval (CI) for the circular variables. As expected, the width of the crescent moon during sighting is generally minimal, and the altitude of the moon is mostly above the horizon though $A R C V$ is more substantial than the altitude of the moon because $A R C V$ considers the position of the sun below the horizon. 
TABLE 3. Summary statistics for linear/circular variables

\begin{tabular}{lccc}
\hline Variable & $\begin{array}{c}\text { Mean direction } \\
(\text { degree })\end{array}$ & $\begin{array}{c}(\text { min, max }) \\
(\text { degree })\end{array}$ & $\begin{array}{c}95 \% \text { CI } \\
(\text { degree })\end{array}$ \\
\hline Width & 0.006 & $(0,0.0 .032)$ & $(0.005,0.007)$ \\
Alt $(S)$ & -1.652 & $(-19.934,4.019)$ & $(-2.094,-1.274)$ \\
Alt $(M)$ & 7.498 & $(-5.460,27.835)$ & $(6.791,8.204)$ \\
ARCV & 9.159 & $(-5.165,26.405)$ & $(8.440,9.957)$ \\
Elon & 10.779 & $(0.563,28.244)$ & $(10.099,11.527)$
\end{tabular}

TABLE 4. Circular correlation between circular variables

\begin{tabular}{|c|c|c|c|c|c|}
\hline Variable & $W$ & $\operatorname{Alt}(S)$ & $\operatorname{Alt}(M)$ & $A R C V$ & Elon \\
\hline \multicolumn{6}{|l|}{$W$} \\
\hline $\operatorname{Alt}(S)$ & -0.233 & & & & \\
\hline $\operatorname{Alt}(M)$ & 0.827 & 0.212 & & & \\
\hline$A R C V$ & 0.924 & -0.334 & 0.850 & & \\
\hline Elon & 0.962 & -0.287 & 0.841 & 0.966 & \\
\hline
\end{tabular}

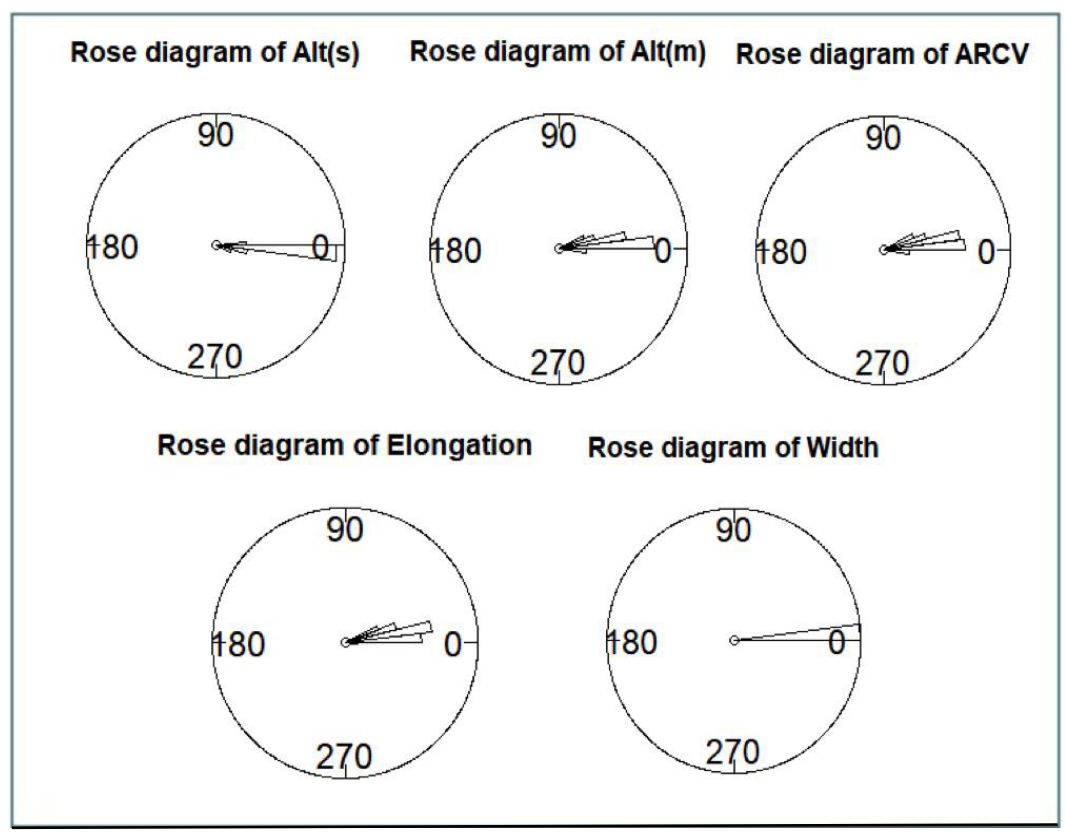

FIGURE 2. Rose diagrams of the circular variables 
We also calculated the correlation values between the variables, which are tabulated in Table 4 . We found that the correlation values of $\operatorname{Alt}(M)-W, A R C V-W$, ElonWidth, ARCV-Alt(M), Elon-Alt(M), and Elon-ARCV are high. Nevertheless, not all the highly correlated variables are suitable to be used as the parameters for crescent visibility. Based on the description of variables as given in Figure 1, ARCV-Alt $(M)$ and Elon- $W$ are expected to be highly correlated as they are collinear to each other. Thus, they are not a good combination of variables for the visibility criteria. As for width, the variation of the values is too small and might affect the relationship with

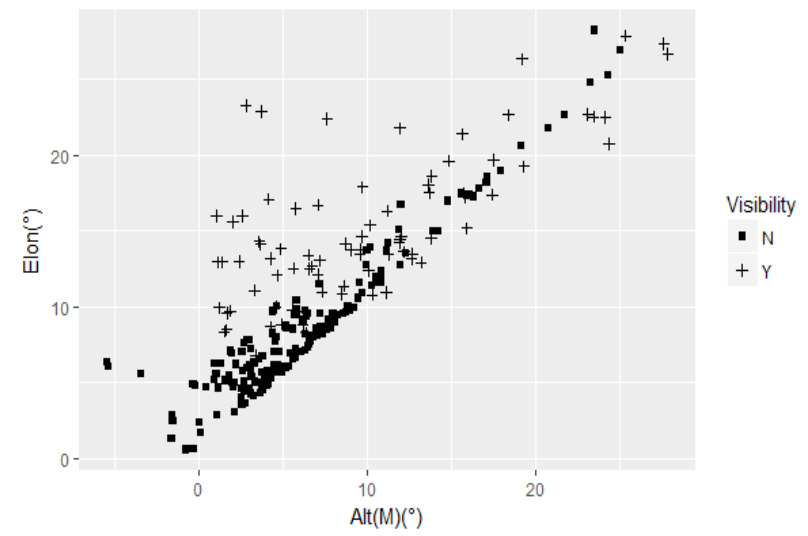

FIGURE 3. Elon versus the $\operatorname{Alt}(M)$ variables

\section{THE NEW VISIBILITY TEST}

For these new visibility test, we use the combination of variables as discussed in Circular Descriptive Analysis section. They are Elon-Alt $(M)$, and Elon-ARCV. We compare the performance of the two new visibility tests by the misclassification percentage of the data.

\section{EA-test}

The new crescent moon visibility test, called $E A$-test, utilizes two circular variables Elon, E, and $\operatorname{Alt}(M)$, A. The best fitted JS circular regression model with $m=1$ is given by

$$
\begin{aligned}
& \cos \hat{E}=0.1832+0.8104 \cos V-0.0372 \sin V \\
& \sin \hat{E}=1.0108-0.9178 \cos V+0.6172 \sin V .
\end{aligned}
$$

other variables (Hoffman 2003). Hence, in this paper, we use the combination of Elon-Alt $(M)$, and Elon-ARCV.

Figures 3 and 4 give the plots of Elon against $\operatorname{Alt}(M)$ and $A R C V$, respectively. The altitude of the moon for $Y$ visibility is recorded at the time of the moon being sighted, which occurs a few minutes after the sunset. In this case, the Sun's altitude is at several degrees below the horizon. Whereas for $N$ visibility, the altitude of the moon is calculated at sunset. Therefore, the distribution of data for $Y$ is expected to be more scattered than $\mathrm{N}$ cases. From both plots, we observed that the larger the values of Elon, ARCV, and $\operatorname{Alt}(M)$, the higher the possibility of sighting the crescent moons.

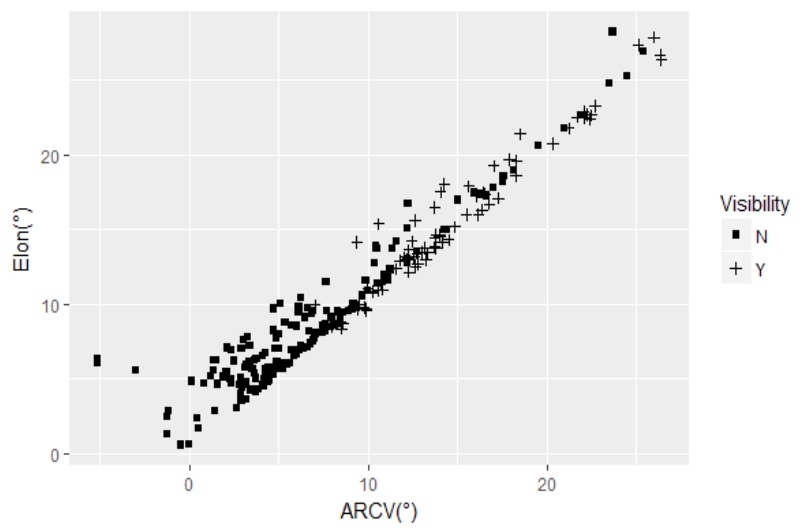

FIGURE 4. Elon versus the $A R C V$

Using the approach adopted by Yallop (1997), we define the $E A$-test, which takes values of residuals of the fitted JS circular regression model. We then attempt to categorize $E A$ using the procedure described in $E A$-test section as tabulated in Table 5. The second column gives the intervals of the categories based on the $E A$-test; for example, Category A consists of observations with $E A$ greater than 0.0086 . The third and fourth columns give the frequency of crescent moon non-visibility $(N)$ and visibility $(Y)$. For Category A, the number of $Y$ is greater than $N$, while for Category $\mathrm{C}$, more $N$ compared to $Y$. Hence, we label Category A as 'Visible to the unaided eye' while Category $\mathrm{C}$ as 'Not visible'. As for Group $\mathrm{B}$, the number of $N$ and $Y$ are fewer with smaller $\mathrm{Y}$ compared to $N$. This might be due to many reasons including the condition of the sky, and hence labelled as 'May need optical aid'. The percentage of correct classification for the $E A$-test is $70.10 \%$.

TABLE 5. Distribution of moon visibility based on three categories

\begin{tabular}{lccccc}
\hline Category & EA-test value & $N$ & $Y$ & Total \% & Interpretation \\
\hline A & {$[0.0086, \infty)$} & 21 & 52 & $73(29)$ & Visible to the unaided eye \\
B & {$[-0.00516,0.0086)$} & 26 & 9 & $35(14)$ & May need optical aid \\
C & $(-\infty,-0.0052)$ & 126 & 20 & $146(57)$ & Not visible \\
\hline
\end{tabular}


Figure 5 gives the plot of $E A$ versus $A l t(M)$. It shows that the residuals separate the $Y / N$ values quite well. Observations with low residuals and small $\operatorname{Alt}(M)$ are largely categorized as non-visible, which is below -0.00156 . For $E A$ above 0.0086 , the moon can be observed by unaided eyes. Otherwise, an optical aid may be needed in the sightings.

\section{EV-test}

We repeat the process using the Elon and $A R C V, V$, denoted as $E V$-test. The best fitted JS regression model with $m=1$ is given by

$$
\begin{aligned}
& \cos \hat{E}=-0.0480+1.0452 \cos V-0.0021 \sin V \\
& \sin \hat{E}=1.5536-1.4884 \cos V+0.5877 \sin V
\end{aligned}
$$

Using the same approach as for the EA-test, the final categories are given in Table 6. The EV-test does not give a good result, with the percentage of correct classification is only $43.7 \%$. This low performance is supported by the plot of $E V$ versus $A R C V$, as given in Figure 6 . The distribution of the residual values of $Y$ and $N$ data are more scattered than that of the EA-test; thus, it fails to separate the $Y$ and $N$ data very well.

TABLE 6. Distribution of moon visibility based on three categories

\begin{tabular}{lccccc}
\hline Category & EV-test value & $N$ & $Y$ & Total \% & Interpretation \\
\hline A & {$[0.0039, \infty)$} & 59 & 21 & $80(31)$ & Visible to the unaided eye \\
B & {$[-0.0022,0.0039)$} & 24 & 16 & $40(16)$ & May need optical aid \\
C & $(-\infty,-0.0022)$ & 90 & 44 & $135(53)$ & Not visible \\
\hline
\end{tabular}

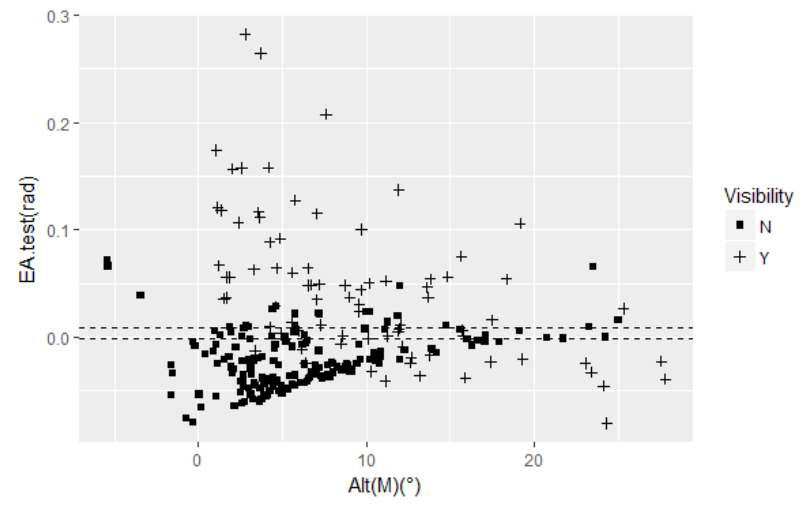

FIGURE 5. $E A$-test versus the $\operatorname{Alt}(M)$

\section{DISCUSSION}

The results in Results and Analysis section indicate that $E A$-test provides the best indicator of visibility of the crescent moon because of the higher percentage of correct detection. Hence, we attempt to come up with the new visibility criteria based on the $E A$-test. The lower limit of the variables is then used as the criteria. In this work, the criteria will be based on Category B of Table 5 as nowadays, telescopes or other optical aid systems are used in the observations. As Elon is taken as the dependent variable in the $E A$-test, we first estimate the criteria value of Elon by its percentile values. The 5th, 10th, and 15 th percentile mean $5 \%, 10 \%$, and $15 \%$ of the ordered observations will be smaller than the percentile values, respectively. That corresponds to 1,3 , and 5 observations

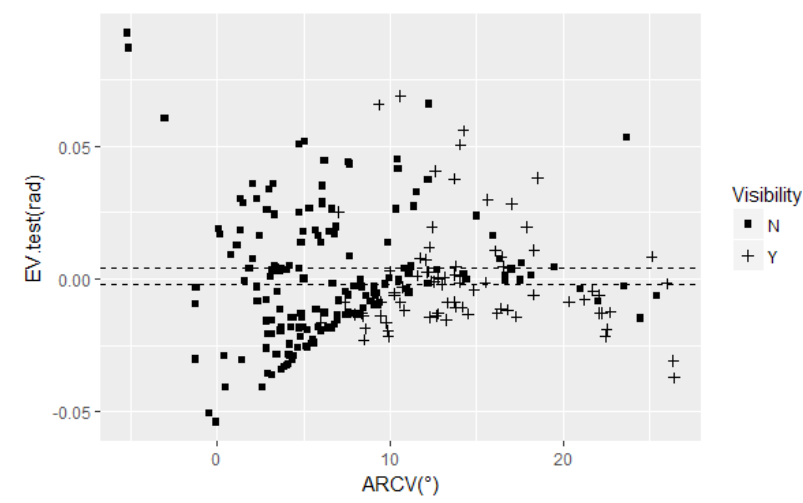

FIGURE 6. $E V$-test versus the $A R C V$

and, hence, the choice of $15 \%$ percentile seems to be adequate for this data. The five observations are listed in Table 7. Most of them have rather low values of $\operatorname{Alt}(M)$ and $A R C V$, which makes it rather difficult to sight the crescent moon after the sunset. Hence, the value of the criteria for Elon is estimated at $7.28^{\circ}$.

As for $\operatorname{Alt}(M)$ and $A R C V$, we consider the plot of Elon-Alt $(M)$ and Elon- $A R C V$, as shown in Figures 7 and 8 , respectively. We then estimate the corresponding values of $\operatorname{Alt}(M)$ and $A R C V$ given that Elon $=7.28^{\circ}$. Hence, the values are $\operatorname{Alt}(M)$ and $A R C V$ are $3.03^{\circ}$ and $3.74^{\circ}$, respectively. Consequently, by definition, the estimated $\operatorname{Alt}(S)$ is taken as the difference between $A R C V$ and $\operatorname{Alt}(M)$, that is $-0.71^{\circ}$. As for $\mathrm{W}$, the observed values are consistently small and we use the 15 th percentile as its estimate, which is $0.1^{\circ}$. We note that the sun's altitude 
of $0.71^{\circ}$ below the horizon has considered the effect of refraction near the horizon and semi-diameter of the sun. During sunset, the centre of the sun is estimated at $0.35^{\circ}$ below the horizon, and hence the estimated time taken for the sun to the altitude $-0.71^{\circ}$ is 1.4 min after it sets.

In determining the final value for the crescent visibility criteria, we use the elongation and altitude of the crescent moon at sunset. We note that the duration of $1.4 \mathrm{~min}$ after sunset is considered negligible to elongation as the average rotation rate of the moon surrounding the earth takes about $0.008^{\circ} / \mathrm{min}$. Hence, the adjusted values of criteria for Elon and $\operatorname{Alt}(M)$ are $7.34^{\circ}$ and $3.33^{\circ}$, respectively, and the corresponding values for $A R C V=3.74^{\circ}$ and $\operatorname{Alt}(S)=$ -0.35 . The final new values of the crescent moon visibility criteria are as listed in Table 8.

TABLE 7. Observations with Elon less than the 15th percentile value

\begin{tabular}{|c|c|c|c|c|c|c|c|}
\hline $\begin{array}{c}\text { Date of } \\
\text { moon } \\
\text { sighting }\end{array}$ & $\begin{array}{l}\text { Date of moon } \\
\text { sighting (Hijr) }\end{array}$ & $\begin{array}{c}\text { Elon } \\
\left({ }^{\circ}\right)\end{array}$ & $\begin{array}{l}\operatorname{Alt}(M) \\
\left({ }^{\circ}\right)\end{array}$ & $A R C V\left(^{\circ}\right)$ & $\begin{array}{c}\operatorname{Alt}(S) \\
\left(^{\circ}\right)\end{array}$ & $\begin{array}{c}\text { Width } \\
\left(^{\circ}\right)\end{array}$ & $\begin{array}{c}\text { Visibility } \\
(\mathrm{Y} / \mathrm{N})\end{array}$ \\
\hline 27.07.2014 & $\begin{array}{c}29 \text { Ramadan } \\
1435\end{array}$ & 7.042 & 2.577 & 2.912 & -0.335 & 0.11 & $\mathrm{~N}$ \\
\hline 10.11 .2007 & $\begin{array}{c}29 \text { Syawal } \\
1428\end{array}$ & 6.898 & 1.963 & 2.314 & -0.351 & 0.11 & $\mathrm{~N}$ \\
\hline 16.09.2012 & $\begin{array}{c}29 \text { Syawal } \\
1433\end{array}$ & 6.286 & 0.945 & 1.361 & -0.416 & 0.1 & $\mathrm{~N}$ \\
\hline 25.04.2009 & $\begin{array}{c}29 \\
\text { Rabiulakhir } \\
1430\end{array}$ & 6.276 & 1.286 & 1.495 & -0.209 & 0.1 & $\mathrm{~N}$ \\
\hline 27.06.2014 & $\begin{array}{c}29 \text { Syaaban } \\
1435\end{array}$ & 4.888 & -0.319 & 0.114 & -0.433 & 0.05 & $\mathrm{~N}$ \\
\hline
\end{tabular}

TABLE 8. The values of new criteria of variables for Category B of the EA-test at sunset

\begin{tabular}{cc}
\hline Variables & Value of criteria $\left({ }^{\circ}\right)$ \\
\hline Elon & 7.28 \\
Alt $(M)$ & 3.33 \\
ARCV & 3.74 \\
Alt $(S)$ & -0.35 \\
Width & 0.10
\end{tabular}

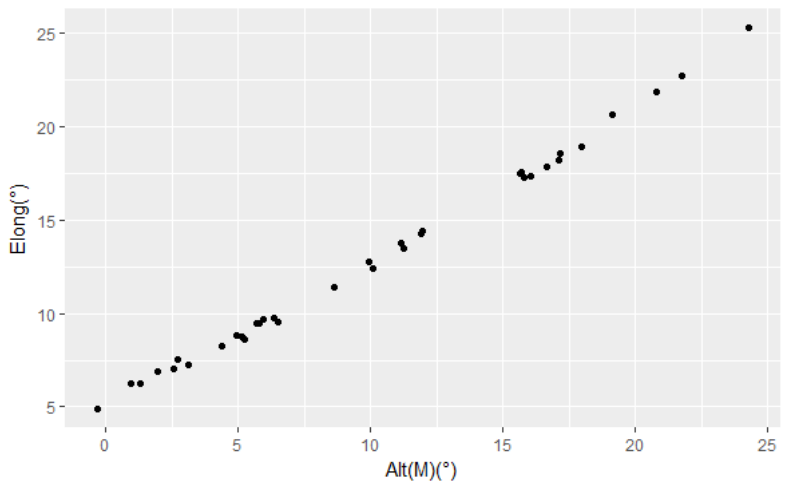

FIGURE 7. Elon vs $\operatorname{Alt}(M)$ for observations Category B of the EA-test

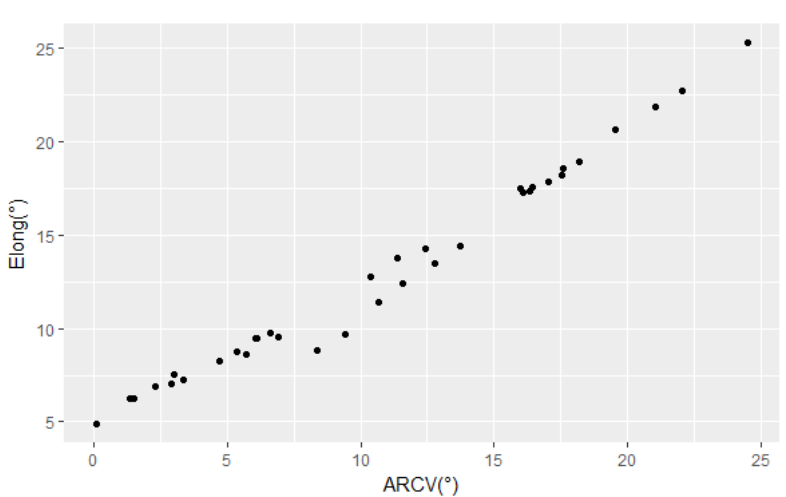

FIGURE 8. Elon vs $A R C V$ for observations in Category B of the $E A$-test 


\section{CONCLUSION}

We consider 254 observations collected consistently every month at Baitul Hilal Teluk Kemang Malaysia for the past 19 years. We derive two new visibility tests based on elongation, the altitude of moon and $A R C V$ of the crescent moon. We divide the test values into three categories, namely, crescent moon visible by the naked eye, visible with optical aid, and not visible. The new criteria are defined based on the observation of the second category, visible with optical aid. We use the 15 th percentile value to be the value of criteria for elongation and width. We then estimate the criteria values of the altitude of the moon and $A R C V$ by utilizing the relationship between Elon-Alt $(M)$ and Elon-ARCV. The criteria are further adjusted so that the elongation and altitude of the crescent moon are measured at sunset. We use the 15 th percentile of the elongation and width and propose the elongation of 7.28 and the width of 7.1 as the new criteria for new crescent moon visibility. Then, we obtain another two criteria values, the altitude of the moon of 3.38, and $A R C V$ of 3.74 using the relationship between Elon-Alt $(M)$ and Elon- $A R C V$, measured at sunset. This new criteria of crescent moon visibility will give an alternative to the authorities in Malaysia to consider the possibility of using them in developing the Islamic calendar.

\section{ACKNOWLEDGEMENTS}

This research was supported by the Department of Islamic Development Malaysia (JAKIM) with cooperation of the Islamic Religious Department of Negeri Sembilan (JAINS) and University Malaya Research Grant IIRG002B-19FNW and IIRG002A-19FNW. We thank our colleagues from Space Physics Laboratory, Department of Physics, Faculty of Science, University of Malaya, especially to Miss Nurhidayah Ismail, Madam Saedah Haron, Mr. Joko Satria Ardianto, Mr. Wei Loon and Mr. Muhammad Shamim as well as the students and academic staffs of Islamic Astronomy Program of Academy of Islamic Studies, University of Malaya, who have willingly helped us out with their abilities in developing the project. Finally, many thanks go to the management of Telok Kemang Observatory and Klana Beach Resort for their kind co-operation and technical support throughout the observations being carried out.

\section{REFERENCES}

Alkasadi, N.A., Ali, H.M., Abuzaid, Safwati Ibrahim, Mohd Irwan Yusoff, (2018). Outliers detection in multiple circular regression model via DFBETAc statistic. International Journal of Applied Engineering 3(11): 9083-9090.

Alrefay, T., Alsaab, S., Alshehri, F., Hadadi, A., Alotaibi, M., Almutari, K. \& Mubarki, Y. 2018. Analysis of observations of earliest visibility of the lunar crescent. The Observatory 138: 267-291.

Best, D.J. \& Fisher, N.I. 1981. The bias of the maximum likelihood estimators of the von Mises-Fisher concentration parameters. Communication in Statistics - Simulations and Computations 10(5): 394-502.

Bruin, F. 1977. The first visibility of the lunar crescent. Vistas in Astronomy 21(4): 331-358.

Danjon, A. 1936. Ann. L'Obs. Strasbourg 3: 139-181.

Fatoohi, L.J., Stephenson, F.R. \& Al-Dargazelli, S.S. 1998. The Danjon limit of first visibility of the lunar crescent. The Observatory: A Review of Astronomy 118: 65-72.

Fisher, N.I. 1993. Statistical Analysis of Circular Data. London: Cambridge University Press.

Fotheringham, J.K. 1910. On the smallest visible phase of the moon. Monthly Notices of the Royal Astronomical Society 70: 527-531.

Guessoum, N. \& Meziane, K. 2001. Visibility of the thin lunar crescent: The sociology of an astronomical problem (A case study). Journal of Astronomical History \& Heritage 4: $1-14$

Hasanzadeh, A. 2012. Study of Danjon limit in moon crescent sighting. Astrophysics and Space Science 339: 211-221.

Hoffman, R.R. 2003. Observing the new moon. Mon. Not. R. Astron. Soc. 340: 1039-1051.

Hogendijk, J.P. 1988. New light on the lunar visibility table of Ya'qub ibn Tariq. Journal of Near Eastern Studies 47: 95-104.

Hussin, A.G., Fieller, N.R.J. \& Stillman, E.C. 2004. Linear regression for circular variables with application to directional data. Journal of Applied Science and Technology 8: $1-6$.

Ilyas Mohammad. 1994. Lunar crescent visibility criterion and Islamic calendar. Quarterly Journal of the Royal Astronomical Society 35: 425-461.

Ilyas Mohammad. 1988. Limiting altitude separation in the new moons 1 st visibility criterion. Astronomy \& Astrophysics 206: 133-135.

Ilyas Mohammad. 1983. The Danjon limit of lunar visibility: A re-examination. The Journal of the Royal Astronomical Society of Canada 77: 214-219.

Jammalamadaka, S.R. \& SenGupta, A. 2001. Topics in Circular Statistics. London: World Scientific.

Jammalamadaka, S.R. \& Sarma, Y.R. 1993. Circular regression. In Statistical Sciences and Data Analysis, edited by Matusita, K. Utrecht, Netherlands: VSP. pp. 109-128.

Kim, S. \& Rifat, M.M.I. 2019. Diagnostic analysis of a circularcircular regression model using asymmetric or asymmetric bi-modal circular errors. Communications in StatisticsTheory and Methods. DOI: 10.1080/03610926.2019.1676448.

Mardia, K.V. \& Jupp, P.E. 1972. Directional Statistics. London: John Wiley and Sons.

Maunder, E.W. 1911. On the smallest visible phase of the moon. The Journal of the British Astronomical Association 21: 355-362.

McNally, D. 1983. The length of the lunar crescent. Quarterly Journal of the Royal Astronomical Society 24: 417-429.

Odeh, M.Sh. 2004. New criterion for lunar crescent visibility. Experimental Astronomy 18: 39-64.

Raharto, M., Sopwan, N., Hakim, M. \& Sugianto, Y. 2019. New approach on study of new young crescent (Hilal) visibility and new month of Hijri calendar. Conference Series, IOP Conf. Series: Journal of Physics: Conf. Series. p. 1170.

Schaefer, B.E. 1996. Lunar crescent visibility. Q.J.R. Astr. Soc. 37: 759-768.

Schaefer, B.E. 1991. Length of the lunar crescent. Quarterly Journal of the Royal Astronomical Society 32: 265-277. 
Schaefer, B.E. 1988. Visibility of the Lunar crescent. Quarterly Journal of the Royal Astronomical Society 29: 511-523.

Sultan, A.H. 2007. First visibility of the lunar crescent: Beyond Danjon's limit. The Observatory: A Review of Astronomy 127: 53-59.

Yallop, B.D. 1997. A Method for Predicting the First Sighting of the New Crescent Moon. Cambridge: Nautical Almanac Office, 1997. NAO Technical Notes, nr. 69.

Zubairi, Y.Z., Hussain, F. \& Hussin, A.G. 2008. An alternative analysis of two circular variables via graphical representation: An application to the Malaysian wind data. Computer and Information Science 1(4): 3-8.

Nazhatulshima Ahmad*

Space Physics Laboratory

Department of Physics

Faculty of Science

University of Malaya

50603 Kuala Lumpur, Federal Territory

Malaysia
Mohd Saiful Anwar Mohd Nawawi \& Mohd Zambri Zainuddin Islamic Astronomy Programme

Department of Fiqh and Usul

Academy of Islamic Studies

University of Malaya

50603 Kuala Lumpur, Federal Territory

Malaysia

Zuhaili Mohd Nasir, Rossita Mohamad Yunus \& Ibrahim Mohamed

Institute of Mathematical Sciences

University of Malaya

50603 Kuala Lumpur, Federal Territory

Malaysia

*Corresponding author; email: n_ahmad@um.edu.my

Received: 22 October 2019

Accepted: 13 January 2020 